\title{
Physical consequences of falls in the elderly: a literature review from 1995 to 2010
}

\author{
Miguel Terroso • Natacha Rosa $\cdot$ Antonio Torres \\ Marques $\cdot$ Ricardo Simoes
}

Received: 10 July 2012 / Accepted: 27 October 2013 / Published online: 13 November 2013

(C) European Group for Research into Elderly and Physical Activity (EGREPA) 2013

\begin{abstract}
In the last decade, population ageing has been registered as a global phenomenon. A relation exists between falling and ageing, since falling frequency increases significantly with age. In fact, one in three older adult falls annually. Although ageing is generically associated with decrease and degeneration of psychological and physical functions, it is still not common for the correct identification of risk factors to lead to a clinical prognosis of the elder being in risk of falling. Therefore, the goal of this review article is to identify, categorise and analyse typical ageing and fall factors mentioned in the literature as well as to quantify the number of times they were referenced. The research considered hundreds of
\end{abstract}

M. Terroso $\cdot$ R. Simoes $(\bowtie)$

School of Technology, Polytechnic Institute of Cávado and Ave,

Campus IPCA, 4750-810 Barcelos, Portugal

e-mail: rsimoes@ipca.pt

R. Simoes

e-mail: rsimoes@dep.uminho.pt

M. Terroso

e-mail: mterroso@ipca.pt

M. Terroso $\cdot$ N. Rosa $\cdot$ A. Torres Marques

Department of Mechanical Engineering, Faculty of Engineering, University of Porto, Rua Dr. Roberto Frias, 4200-465 Porto, Portugal

N. Rosa

e-mail: nrosa@fe.up.pt

A. Torres Marques

e-mail: marques@fe.up.pt

\section{R. Simoes}

Institute for Polymers and Composites IPC/I3N, University of Minho, 4800-058 Guimarães, Portugal

\section{R. Simoes}

Life and Health Sciences Research Institute (ICVS), School of Health Sciences, University of Minho, Campus de Gualtar, 4710-057 Braga, Portugal publications, but analysis was then restricted to the 87 most pertinent articles written in English and published in journals or scientific magazines between 1995 and 2010. We concluded that falls among older adults can be characterised by the following: anatomic characteristics and physiological consequences of ageing; the pathologies that induce falls, which can be neurological, musculoskeletal, cardiovascular and other diseases; causes and risk factors of falls that can be behavioural, biological, environmental or socio-economic; type of physical consequences of falls, including fractures, bruises, injuries or other physical consequences; and strategies to prevent, mitigate or rehabilitate, which can be of a physical, environmental or behavioural nature.

Keywords Ageing $\cdot$ Elderly falls $\cdot$ Accidental falls $\cdot$ Risk factors $\cdot$ Physical consequences of falls

\section{Introduction}

Elderly are currently considered the fastest growing age group worldwide [13]. In the last decades, the number of elderly people in the world has been consistently and proportionally increasing. In 1996, there were a total of 323 million people in the world aged above 65 years [49]. That number increased in 2010 to 440 million [13] and is forecasted to be 1,555 million by 2050 [49].

The physical changes inherent to ageing can reduce autonomy and functional independence, which may directly or indirectly lead to falls. Falls are coded as E880-E888 in the International Classification of Disease-9 (ICD-9) and as W00-W19 in ICD-10, being commonly defined as "inadvertently coming to rest on the ground, floor or other lower level, excluding intentional change in position to rest in furniture, wall or other objects" [84]. About one third of the population 
over 65 suffers at least one indoor fall every year [33, 47], and about half of the population in this age group who is institutionalised fall each year [33]. Among the elderly, falls are one of the main causes of injuries, physical incapacity and even death. Each year, around 37.3 million falls among elderly will require health care, and about 424,000 lead to death of the faller [19].

It is thus obvious that the problem of falls among the elderly population has epidemiological levels with a global incidence and dimension. Therefore, the following question was posed: What are the physical consequences of falls in the elderly population?

In order to answer this question, a quantitative review was conducted. This paper aims at identifying, categorising and analysing the typical ageing and fall factors mentioned in the literature as well as quantifying the number of times these factors were referenced. This study considered the incidence of the anatomic characteristics and physiological consequences of ageing, the pathologies that power falls, causes and risk factors for falls, physical consequences of falls and strategies to prevent, mitigate and rehabilitate.

This work is focused on providing an overview of the published literature to researchers, academics and practitioners, who deal with this issue; it does not cover the entire research area of elderly population falls.

\section{Materials and methods}

The research was limited to peer-reviewed articles, written in English and published in scientific journals or magazines between the years 1995 and 2010. The research was restricted to the following databases: PubMed, Access Medicine, Science Direct, Oxford Journals and Taylor \& Francis Online. Additionally, a manual search was carried out for the other publishers in the areas already mentioned, such as McGraw-Hill and BioMed Central as well as publications edited by organisations that focus the problem of falls in the elderly people, such as the National Center for Injury Prevention and Control and the World Health Organization.

The keywords used, as title and/or abstract and/or keywords of the articles, either for searching scientific publications databases or for manual search in other online publications, were the following: "physical consequences of falls", "senior population and falls", "falls pathologies", "anatomy of ageing", "causes of falls" and "risk factors".

After the search, the titles and abstracts were analysed in order to eliminate duplicates and publications with topics that did not meet the purpose of this review work. The remaining publications were thoroughly read and analysed, and all references to the topics addressed in the review article were identified and quantified.

\section{Search results}

A total of 87 publications were selected and analysed, from which 81 were journal publications from scientific database and 6 were articles published in book chapters or specialty reports obtained from the manual search. The publications came from 25 different countries in the world and represent all continents with the exception of Africa. The strongest geographic incidence, with about $82 \%$ of the total publications was identified in two continents: North America and Europe. South America and Asia represent $18 \%$ of the total publications. Publications from Turkey, Israel and Iran were considered as being from the Asian continent.

Ageing pathologies that potentiate falls

Falls are events that depend on multiple factors and can be related to the presence of pathologies. The pathologies inherent to the process of ageing, which may lead to fall in the elderly population, are numerous and diverse. Therefore, four categories were considered: neurological, musculoskeletal, cardiovascular and other pathologies (see Table 1). The neurologic and musculoskeletal pathologies were the most referenced in the analysed literature. The cardiovascular pathologies also had a considerable incidence of references, although small when compared with the former. Table 1 shows the references in the literature for each pathology type and the number of times they were referenced (in percentage).

In the selected literature, the neurological diseases, such as stroke (13.7\%), dementia (10.3\%), vestibular disorders/ balance (10.3\%) and Parkinson (9.1\%), are the most referenced ageing pathologies as propitiating falls in the elderly population.

In terms of musculoskeletal pathologies, osteoporosis was the pathology with a higher incidence of references $(16 \%)$, followed by loss of muscle density $(9.1 \%)$ and arthritis $(6.8 \%)$. Problems in the lower extremities and joint deformities were also diseases common in the falling elderly, but with a lower incidence of references (3.4 and $2.2 \%$, respectively).

Cardiovascular diseases, such as orthostatic hypotension (6.8\%), arrhythmias (3.4\%) and syncope (3.4\%), are also common pathologies due to the ageing process and may also lead to falls.

In the "other pathologies" category, the following typical pathologies of ageing that can lead to falls were identified: diabetes and depression (4.5\%), pneumonia and lung infections $(2.2 \%)$ and sleep disorders $(1.1 \%)$.

The causes and risk factors of falls

Table 2 identifies multiple causes and risk factors of falls in the elderly population as well as the respective incidence in the reviewed literature. The causes and risk factors of falls are 
Table 1 Identification of references for pathologies of ageing that may cause falls
${ }^{\mathrm{a}}$ The percentages refers to a total of 87 publications

\begin{tabular}{lll}
\hline & $N(\%)^{\mathrm{a}}$ & References \\
\hline Neurological diseases & & \\
Stroke & 13.7 & {$[13,21,33,40,44,45,53,57,63,75,81,86]$} \\
Dementia & 10.3 & {$[17,21,33,40,45,53,60,63,86]$} \\
Vestibular disorders/balance & 10.3 & {$[22,33,40,53,54,63,64,68,87]$} \\
Parkinson & 9.1 & {$[6,33,40,45,53,63,64,69]$} \\
Multiple sclerosis & 1.1 & {$[62]$} \\
Musculoskeletal diseases & & \\
Osteoporosis & 16.0 & {$[4,5,14,17,24,25,30,37,40,43,56,62,63,71]$} \\
Loss of muscle density & 9.1 & {$[14,23,25,33,40,63,81,83]$} \\
Arthritis & 6.8 & {$[21,45,53,63,64,86]$} \\
Problems in the lower extremities & 3.4 & {$[33,45,53]$} \\
Deformities in the joints & 2.2 & {$[33,53]$} \\
Cardiovascular diseases & & \\
Orthostatic hypotension & 6.8 & {$[33,40,53,56,63,86]$} \\
Arrhythmias & 3.4 & {$[22,45,53]$} \\
Syncope & 3.4 & {$[53,57,58]$} \\
Others & 8.0 & {$[9,13,22,33,45,53,64]$} \\
Other pathologies & & {$[21,53,63,86]$} \\
Diabetes & 4.5 & {$[53,63,64,86]$} \\
Depression & 4.5 & {$[14,53]$} \\
Pneumonia and bone infections & 2.2 & \\
Sleep disorders & 1.1 & \\
\hline
\end{tabular}

very diverse, and several of these factors can occur simultaneously. Due to that diversity, the causes and risk factors of falls were grouped in four categories, analogous to those adopted by the World Health Organization, in WHO Global Report on Falls Prevention in Older Age [84]:

- Behavioural, characteristics of human actions, emotions or daily choices;

- Biological, individual's characteristics pertinent to the human body;

- Environmental, interactions between the individual's physical condition and the surrounding environment;

- Socio-economic, related to the individual's social and economic situation.

The results of this analysis are shown in Table 2. The behaviour causes and risk factors most referenced in the reviewed literature were overdose of medication (with $32.1 \%$ ) and the fear of falling - without having ever fallen before or after the first fall (29.8 and $22.9 \%$, respectively). The reduction in physical activity (16\%), carrying out activities of daily living $(11.4 \%)$ and alcohol consumption $(10.3 \%)$ are located in the intermediate incidence group. In the smallest incident group, the following were identified: slip $(6.8 \%)$, fainting $(4.5 \%)$ as well as smoking and an inappropriate use of footwear (both with $3.4 \%$ ).

Concerning the biological causes and risk factors, highest incidence was on a lack of balance during gait (33.3\%), musculoskeletal and sensory degradation (26.4\%), functional dependence in the mobility (25.2\%), cognitive impairment (24.1\%), age (19.5\%) and sex (18.3\%) with higher incidence in females. The decrease in bone density and lack of vision (with $14.9 \%$ each), chronic diseases (13.7\%), depression $(12.6 \%)$, occurrence of dizziness and vertigo (11.4\%) and decrease of index bone mass (10.3\%), which weakens the ability to absorb and dissipate impact forces, were intermediate incidence factors. Finally, urinary incontinence, orthostatic hypotension, pain, soft tissue changes, hearing problems and body weight, with between 3.4 and $4.5 \%$ incidence, were identified as causes and behaviour risk factors with least references in the reviewed literature.

With respect to the environmental causes and risk factors, unsafe domestic (17.2\%) and outdoors (16\%) environments were found to have the highest incidence. Falls from hospital beds, mobility aids (for example walkers) and the collision against objects were referenced only one to two times.

Last, the socio-economic causes and risk factors of falls included limited access to health and social services (2.2\%), low income and low educational level (2.2\%) and lack of social interactions $(1.1 \%)$. This category had the lowest number of references in the literature, when compared with the other categories of causes and risk factors.

If a profile is established for a senior individual with a high risk of falling based simultaneously on the causes and risk factors more referenced on the four categories, the overall risk 
Table 2 Identification of references and percentage of incidence of the causes and risk factors for falls

\begin{tabular}{|c|c|c|}
\hline & $N(\%)^{\mathrm{a}}$ & References \\
\hline \multicolumn{3}{|l|}{ Behavioural } \\
\hline Medication (overdose) & 32.1 & {$[3,5,7-9,13,17,19,21,22,84,33,39,40,48,53,55-57,60,61,63,66,70,71,77,78,86]$} \\
\hline Fear of falling (after the first fall) & 29.8 & {$[1,13,18,20,25,32,33,37-39,41,47,52,53,56,62,63,67,68,70,76-78,81,86]$} \\
\hline $\begin{array}{l}\text { Fear of falling (without ever having } \\
\text { fallen) }\end{array}$ & 22.9 & {$[6,13,18,20,25,32,33,38,39,41,52,53,62,63,67,76,77,79,81,85]$} \\
\hline Reduction of physical activity & 16.0 & {$[6,19,20,23,84,39-41,55,63,71,75,77,86]$} \\
\hline Activities of daily living & 11.4 & {$[13,20,21,25,29,36,39,63,81,86]$} \\
\hline Alcohol consumption & 10.3 & {$[2,13,19,84,40,53,55,63,70]$} \\
\hline Slip/slide & 6.8 & {$[23,33,40,45,46,64]$} \\
\hline Direction of fall (sideways) & 4.5 & {$[14,24,25,49]$} \\
\hline Fainting & 4.5 & {$[13,33,55,57]$} \\
\hline Inappropriate footwear & 3.4 & {$[17,84,48]$} \\
\hline Smoking & 3.4 & {$[40,55,63]$} \\
\hline Direction of fall (forward) & 2.2 & {$[14,23]$} \\
\hline Difficulties in dressing & 1.1 & {$[55]$} \\
\hline Level/angle/position of the impact & 1.1 & {$[40]$} \\
\hline \multicolumn{3}{|l|}{ Biological } \\
\hline Lack of balance while walking & 33.3 & {$[2,5-7,9,13,14,17,19,20,22,23,31,33,39,40,45,48,53,55,62,63,66-70,81,86]$} \\
\hline $\begin{array}{l}\text { Musculoskeletal and sensory } \\
\text { degradation }\end{array}$ & 26.4 & {$[3,5-7,13,14,17,22,23,84,40,45,53,55,61-64,66,69,71,78,81]$} \\
\hline Functional dependence on mobility & 25.2 & {$[7,9,12,19-21,23-26,35,39,40,50,53,55,56,62,67,71,77,78]$} \\
\hline Cognitive impairment & 24.1 & {$[6,7,9,13,17,19-23,84,45,55,59,63,64,69,70,75,77,81]$} \\
\hline Age & 19.5 & {$[5,10,12,84,34,36,40,49,55,56,63,66,70,71,78,86]$} \\
\hline Sex (higher incidence in females) & 18.3 & {$[3,5,13,84,35,40,43,48,49,56,63,67,70,78,80,86]$} \\
\hline Decreased bone density & 14.9 & {$[5,14,24,25,84,34,40,43,49,56,62,63,71]$} \\
\hline Lack of vision & 14.9 & {$[7,13,17,22,40,48,53,55,56,63,77,86,87]$} \\
\hline Chronic disease & 13.7 & {$[9,13,22,84,33,40,48,55,63,69,70,86]$} \\
\hline Depression & 12.6 & {$[2,13,17,26,33,55,63,67,70,77,81]$} \\
\hline Dizziness/vertigo & 11.4 & {$[7,13,17,22,40,48,53,55,56,63,77,86,87]$} \\
\hline Decrease in body mass index & 10.3 & {$[5,7,10,25,29,40,49,55,71]$} \\
\hline Pains & 4.5 & {$[3,6,35,56]$} \\
\hline Changes in soft tissues & 4.5 & {$[14,40,57,64]$} \\
\hline Urinary incontinence & 3.4 & {$[33,56,61]$} \\
\hline Postural hypotension & 3.4 & {$[17,56,61]$} \\
\hline Weight (body mass that falls) & 3.4 & {$[25,40,63]$} \\
\hline Hearing problems & 3.4 & {$[13,55,63]$} \\
\hline \multicolumn{3}{|l|}{ Environmental } \\
\hline Unsafe home environments & 17.2 & {$[5,7,15,17,22,25,84,33,48,55,63,65,66,71,86]$} \\
\hline Unsafe outdoors & 16.0 & {$[5,7,15,17,19,22,25,84,33,48,55,66,71,86]$} \\
\hline Height of fall & 2.2 & {$[14,25]$} \\
\hline Collision with objects & 2.2 & {$[23,55]$} \\
\hline Mobility aids & 2.2 & {$[40,63]$} \\
\hline Falls hospital beds & 1.1 & {$[27]$} \\
\hline \multicolumn{3}{|l|}{ Socio-economic } \\
\hline Level of education and income & 2.2 & {$[84,78]$} \\
\hline Access to social services and health & 2.2 & {$[84,78]$} \\
\hline Lack of social interaction & 1.1 & {$[84]$} \\
\hline
\end{tabular}

${ }^{\mathrm{a}}$ The percentages refer to a total of 87 publications 
of falling and consequent injury gravity for that individual can be expected to be very high.

Physical consequences of falls and physiological effects

Falls among the elderly are associated with a large diversity and heterogeneity of undesired physical consequences, which can be more or less severe. Four main categories were considered for the physical consequences: fractures, bruises, injuries and "other" physical consequences. A fifth category was also defined, focused on the physiological effects associated to the physical consequences of falls.

The results concerning the physical consequences and the physiological effects of falls are shown in Table 3. It was observed that fractures (as consequences of falls) can occur in almost every region in the body. However, the hip fracture and undifferentiated bone fractures are the most referenced in the literature, with 37.9 and $27.5 \%$ incidence, respectively.

Table 3 Identification of references of physical consequences of falls and its physiological effects

\begin{tabular}{|c|c|c|}
\hline & $N(\%)^{\mathrm{a}}$ & References \\
\hline \multicolumn{3}{|l|}{ Fractures } \\
\hline Hip fracture & 37.9 & $\begin{array}{l}{[1,2,4,5,10,11,14,16,21,24,25,30,84,33,36,40,42,47,49,53,55,57-59,62,64,} \\
\quad 70-72,80,81,86,87]\end{array}$ \\
\hline Undifferentiated bone fractures & 27.5 & {$[5,13,14,21,25,33,35,37,40,43,47,58,61,63,64,70,74,75,77,78,80-82,86]$} \\
\hline Trochanteric femoral fractures & 5.7 & {$[33,40,57,58,74]$} \\
\hline Fractures in the trunk & 4.5 & {$[14,33,40,47]$} \\
\hline Neck fractures & 4.5 & {$[14,47,57,58]$} \\
\hline Fractures of the upper limbs & 3.4 & {$[14,40,47]$} \\
\hline Fracture of the humerus & 2.2 & {$[33,40]$} \\
\hline Fractures in the chest & 1.1 & {$[82]$} \\
\hline Broken knee & 1.1 & {$[40]$} \\
\hline \multicolumn{3}{|l|}{ Bruises } \\
\hline Head bruises & 10.3 & {$[13,14,35,53,58,62,70,77,86]$} \\
\hline Bruises and abrasions & 3.4 & {$[35,47,75]$} \\
\hline Bruises with blood loss & 1.1 & {$[70]$} \\
\hline \multicolumn{3}{|l|}{ Injuries } \\
\hline Soft tissue injuries & 6.8 & {$[14,33,35,43,62,86]$} \\
\hline Injuries in the upper extremities & 5.7 & {$[14,40,62,64,75]$} \\
\hline Traumatic brain injury & 4.5 & {$[14,84,70,75]$} \\
\hline Injuries in wrists & 4.5 & {$[14,33,40,47]$} \\
\hline Injuries in the lower extremities & 3.4 & {$[33,62,75]$} \\
\hline Injuries in the elbow & 2.2 & {$[14,40]$} \\
\hline \multicolumn{3}{|l|}{ Physiological effects } \\
\hline Death or morbidity & 21.8 & {$[5,9,22,25,84,33,35,47,49,51,55,60,62-64,66,67,71]$} \\
\hline Functional decline & 20.6 & {$[5,13,23,25,35,40,41,49,52,53,55,64,67,70,71,76,78,81]$} \\
\hline Inactivity & 14.9 & {$[3,6,13,35,41,47,52,53,63,67,70,77,81]$} \\
\hline Functional dependency and loss of autonomy & 13.7 & {$[84,33,35,41,49,52,71,76-78,81,86]$} \\
\hline Depression & 10.3 & {$[13,84,35,53,55,63,67,70,81]$} \\
\hline Loss of self-confidence & 5.7 & {$[25,33,35,67,76]$} \\
\hline Loss of self-efficacy & 2.2 & {$[41,67]$} \\
\hline \multicolumn{3}{|l|}{ Others } \\
\hline Lacerations & 8.0 & {$[35,47,58,62,70,75,86]$} \\
\hline Dislocations & 5.7 & {$[14,41,70,77,81]$} \\
\hline Sprains & 3.4 & {$[14,35,70]$} \\
\hline Pains & 2.2 & {$[35,70]$} \\
\hline Hematoma & 1.1 & [33] \\
\hline
\end{tabular}

${ }^{\mathrm{a}}$ The percentages refer to a total of 87 publications 
The head bruises due to falls, with $10.3 \%$ incidence, were the more referred physical consequence in the bruises category.

For the injuries category, the incidence of references in the literature is more homogeneous than in other categories. The most referenced injuries are soft tissues and the upper extremities, respectively with 6.8 and $5.7 \%$ incidence. Injuries on the elbows are the ones that had the least incidence, namely $2.2 \%$.

For other consequences, lacerations with $8 \%$ and dislocations with $5.7 \%$ incidence were the most referenced in the literature. This category also included sprains, hematomas and pain, but these were identified in the literature to a smaller extent.

The physiological effects of elderly falls were also identified. The two effects with higher incidence of references were death and morbidity, with $21.8 \%$, and functional decline, with $20.6 \%$. Other still significant effects were inactivity, with $14.9 \%$, functional dependence and loss of autonomy, with $13.7 \%$, and depression, with $10.3 \%$ incidence.

This analysis reveals a possible cause-effect relation between the different physiological effects. For example, depression can lead to higher functional dependence; in the same way, inactivity can lead to functional decline. On the other hand, the state of physical incapacity and functional dependence as a result of a fall can retract the ability to participate in everyday life activities and increase the chance of depression. These interrelations between causes will be further explored in future work.

Interventions for prevention, rehabilitation and minimization of falls

Many actions, strategies and mechanisms can-and have been-employed for the prevention, minimization and rehabilitation aspects of elderly falls. The different interventions can be categorised into three groups: the first group consists of physical interventions, the second of environmental interventions, and the third with behavioural interventions. For each of those, one can correspond them to the three stages associated with falls: the moment before the fall (interventions to prevent falls), the time during the fall (interventions to minimise the consequences of falls) and the moment after the fall (interventions related with the rehabilitation of the consequences of falls).

The different interventions, related to falls, as well as the respective percentage of references incidence are indicated in

Table 4 Identification of references and percentage of incidence, for physical, environmental and behavioural interventions for prevention, minimization and rehabilitation of falls in the elderly

$\operatorname{Pr} \mathrm{Mi} \operatorname{Re} N(\%)$ References

\begin{tabular}{|c|c|c|c|c|c|}
\hline \multicolumn{6}{|l|}{ Physical interventions } \\
\hline Adjustment of medication & $\mathrm{x}$ & & $\mathrm{x}$ & 18.3 & $\begin{array}{l}{[8,13,17,19,25,84,33,35,39,53,55,61,63,} \\
\quad 72,81,86]\end{array}$ \\
\hline Protective coating systems can reduce hip fracture risk in the event of a fall. & & $\mathrm{x}$ & & 17.2 & $\begin{array}{l}{[5,7,10,11,16,17,19,25,30,35,40,42,59} \\
\quad 62,63]\end{array}$ \\
\hline Use of nutrition programmes (calcium and vitamin D) & $\mathrm{x}$ & $\mathrm{x}$ & $\mathrm{x}$ & 11.4 & {$[4,5,17,19,25,33,35,51,53,63]$} \\
\hline Mobility aids & $\mathrm{x}$ & $\mathrm{x}$ & $\mathrm{x}$ & 5.7 & {$[5,17,19,24,62]$} \\
\hline Increase and maintain bone mass and strength through exercise & $\mathrm{x}$ & $\mathrm{x}$ & & 4.5 & {$[23,25,61,81]$} \\
\hline Vision interventions (cataract surgery) & $\mathrm{x}$ & & & 4.5 & {$[17,19,35,73]$} \\
\hline Use of appropriate footwear & $\mathrm{x}$ & & $\mathrm{x}$ & 4.5 & {$[5,17,35,48]$} \\
\hline \multicolumn{6}{|l|}{ Environmental interventions } \\
\hline Changes in the home and public environment to reduce the risk of falling & $\mathrm{x}$ & & & 11.4 & {$[1,5,17,19,28,84,35,65,71,73]$} \\
\hline Removal of obstacles in the household & $\mathrm{x}$ & & & 4.5 & {$[28,33,55,62]$} \\
\hline \multicolumn{6}{|l|}{ Behavioural interventions } \\
\hline Increased physical activity and exercise & $\mathrm{x}$ & $\mathrm{x}$ & $\mathrm{x}$ & 21.8 & $\begin{array}{l}{[2,5,6,13,14,17,19,23,25,84,33,35,51} \\
\quad 53,55,63,66,71,73]\end{array}$ \\
\hline Methods based on the rehabilitation gait training & & & $\mathrm{x}$ & 14.9 & {$[5,17,28,33,35,44,45,53,55,62,71,79,81]$} \\
\hline Evaluation and management of risk factors for multiple falls & $\mathrm{x}$ & & & 10.3 & {$[33,39,51,56,58,60,71,74,76]$} \\
\hline $\begin{array}{l}\text { Evaluation of the people who have fallen or at risk of falling, } \\
\text { to identify modifiable risk factors }\end{array}$ & $\mathrm{x}$ & & $\mathrm{x}$ & 5.7 & {$[35,39,53,60,76]$} \\
\hline Strategies to modify risk behaviours of the patient falling & $\mathrm{x}$ & & & 5.7 & {$[17,28,39,60,76]$} \\
\hline Mechanisms that characterise the cognitive changes associated with ageing. & $\mathrm{x}$ & & & 4.5 & {$[39,45,63,86]$} \\
\hline
\end{tabular}

${ }^{\text {a }}$ The percentages refer to a total of 87 publications

$\operatorname{Pr}$ prevention, Mi minimization, Re rehabilitation 
Table 4. For each type of intervention (physical, environmental and behavioural), Table 4 also shows at which stage of the fall event they can be applied (prevention, minimization and rehabilitation). Note that these stages are not mutually exclusive.

The physical interventions are those that represented the highest incidence: most notably, adjustment of medication with $18.3 \%$ incidence, hip protection coating systems with $17.2 \%$ incidence and the use of strengthening nutrition programmes with $11.4 \%$ incidence.

The environmental interventions were those that exhibited the lowest incidence and were essentially limited to changes in the home and public environments to reduce the risk of fall, with $11.4 \%$ incidence. Note also that the other intervention "removal of obstacles in the household" is directly related to the former.

Finally, in the behavioural interventions, the highest incidence, of $21.8 \%$, was found for carrying out activities and exercise. The use of rehabilitation methods based on gait training and management of risk factors of multiple falls, with an incidence of 14.9 and $10.3 \%$, respectively, were also relevant types of behavioural interventions.

\section{Concluding remarks}

In this review article, we have quantitatively characterised relevant research efforts on this issue of great social relevant over the last decade and a half, by identifying the incidence of articles concerning the anatomic characteristics and physiological consequences of ageing, the pathologies that propitiate falls, the causes and risk factors for falls, the physical consequences of falls and the strategies to prevent, minimise or rehabilitate.

This study will be useful both for those who want to identify key research issues and those who study ageing from the perspective of social sciences. In the future, repeating this study for the period of 2011-2025 will provide a historical time frame for analysis and comparison.

In subsequent work, we aim to study the economic impact of falls, from the individual and societal perspectives.

\footnotetext{
Acknowledgments We acknowledge the Foundation for Science and Technology (FCT), Lisbon, through the $3^{\circ}$ Quadro Comunitario de Apoio, the POCTI and FEDER programmes, project PEst-C/CTM/ LA0025/2013, and FCT scholarship SFRH/PROTEC/67465/2010. Partial support has been provided by project PT21, no. 13848, co-financed by the European Community Fund through COMPETE Programa Operacional Factores de Competitividade. The financial sponsors played no role in the design, execution, analysis and interpretation of data or writing of the study.
}

Conflict of interest The authors have no conflict of interest to disclose.

\section{References}

1. Abolhassani F, Moayyeri A, Naghavi M, Soltani A, Larijani B, Shalmani H (2006) Incidence and characteristics of falls leading to hip fracture in Iranian population. Bone 39:408-413

2. Allander E, Gullberg B, Johnell O, Kanis J, Ranstam J, Elffors L (1998) Circumstances around the fall in a multinational hip fracture risk study: a diverse pattern for prevention. Accid Anal Prev 30(5): 607-616

3. Blyth F, Cumming R, Mitchell P, Wang J (2007) Pain and falls in older people. Eur J Pain 11:564-571

4. Bonjour J, Schurch M, Rizzoli R (1996) Nutritional aspects of hip fractures. Bone 18(3):1395-1445

5. Boonen S, Dejaeger E, Vanderschueren D, Venken K, Bogaerts A, Verschueren S, Milisen K (2008) Osteoporosis and osteoporotic fracture occurrence and prevention in the elderly: a geriatric perspective. Best Pract Res Clin Endocrinol Metab 22(5):765-785

6. Canning C, Sherrington C, Lord S, Fung V, Close J, Latt M, Howard K, Allen N, O'Rourke S, Murray S (2009) Exercise therapy for prevention of falls in people with Parkinson's disease: a protocol for a randomised controlled trial and economic evaluation. BioMed Central Neurology. http://www.biomedcentral.com/1471-2377/9/4. Accessed Oct 2010

7. Chan D, Hillier G, Coore M, Cooke R, Monk R, Mills J, Hung W (2000) Effectiveness and acceptability of a newly designed hip protector: a pilot study. Arch Gerontol Geriatr 30:25-34

8. Chang C, Chen M, Tsai C, Ho L, Chau Y, Liu C (2010) Medical conditions and medications as risk factors of falls in the inpatient older people: a case-control study. Int J Geriatr Phychiatr 26(6):602-607

9. Chen Y, Hwang S, Chen L, Chen D, Lan C (2008) Risk factors for falls among elderly men in a veterans home. J Chin Med Assoc 71(4): $180-185$

10. Choi W, Hoffer J, Robinovitch S (2010) Effect of hip protectors, falling angle and body mass index on pressure distribution over the hip during simulated falls. Clin Biomech 25:63-69

11. Choi W, Hoffer J, Robinovitch S (2010) The effect of positioning on the biomechanical of soft shell hip protectors. J Biomech 43:818-825

12. Church S, Robinson T, Aangles E, Tran Z, Wallace J (2011) Postoperative falls in the acute hospital setting: characteristics, risk factors, and outcomes in males. Am J Surg 201(2):197-202

13. Coimbra A, Ricci N, Coimbra I, Costallat L (2010) Falls in the elderly of the family health program. Archives of Gerontology and Geriatrics 51(3):317-322

14. Degoede K, Ashton-Miller J, Schultz A (2003) Fall-related upper body injuries in the older adult: a review of the biomechanical issues. J Biomech 36:1043-1053

15. Demura S, Sato S, Yamaji S, Kasuga K, Nagasawa Y (2010) Examination of validity of risk assessment items for screening high fall risk elderly among the healthy community-dwelling Japanese population. Archives of Gerontology and Geriatrics 53(1):e41-e45

16. Derler S, Spierings A, Schmitt K (2005) Anatomical hip model for the mechanical testing of hip protectors. Med Eng Phys 27:475-485

17. Easterbrook L, Horton K, Arber S, Davidson K (2001) International review of interventions in falls among older people. London: a report for the Health Development Agency, Department of Trade and Industry. http://www.viewcare.co.uk/Publications/fallsint.pdf. Accessed Sep 2010

18. Faes M, Reelick M, Melis R, Borm G, Esselink R, Olde M (2010) Multifactorial fall prevention for pairs of frail community-dwelling older fallers and their informal caregivers: a dead end for complex interventions in the frailest fallers. Journal of American Medical Directors Association 12(6):451-458

19. Falls (2010) Geneva: World Health Organization, media centre, fact sheet no. 344, August. http://www.who.int/mediacentre/factsheets/ fs344/en. Accessed Mar 2011 
20. Fletcher P, Guthrie D, Berg K, Hirdes J (2010) Risk factors for restriction in activity associated with fear of falling among seniors within the community. J Pacient Saf 6(3):187-191

21. Formiga F, Navarro M, Duasco E, Chivite D, Ruiz D, Perez-Castejon J, Lopez-Soto A, Pujol R (2008) Factors associated with hip fracturerelated falls among patients with a history of recurrent falling. Bone 43:941-944

22. Gama Z, Conesa A (2008) Morbilidad, factores de riesgo y consecuencias de las caídas en ancianos. Fisioterapia 30(3):142151

23. Grabiner M, Donovan S, Bareither M, Marone J, Hamstra-Wright K, Gatts S, Troy K (2008) Trunk kinematics and fall risk of older adults: translating biomechanical results to the clinic. J Electromyogr Kinesiol 18:197-204

24. Greenspan S, Myers E, Kiel D, Parker R, Hayes W, Resnick N (1998) Fall direction, bone mineral density, and function: risk factors for hip fracture in frail nursing home elderly. Am J Med 104(6):539545

25. Hayes W, Myers E, Robinovitch S, Van Den Kroonenberg A, Courtney A, Mcmahon T (1996) Etiology and prevention of agerelated hip fractures. Bone 18(1):77S-86S

26. Hendrich A, Nyhuis A, Kippenbrock T, Soja M (1995) Hospital falls: development of a predictive model for clinical practice. Appl Nurs Res 8(3):129-139

27. Hilbe J, Schulc E, Linder B, Them C (2010) Development and alarm threshold evaluation of a side rail integrated sensor technology for the prevention of falls. Int J Med Inform 79(3):173-180

28. Hill A, Hill K, Brauer S, Oliver D, Hoffmann T, Beer C, Mcphail S, Haines T (2009) Evaluation of the effect of patient education on rates of falls in older hospital patients: description of a randomised controlled trial. BioMed Central Geriatrics. http://www.biomedcentral. com/1471-2318/9/14. Accessed Oct 2010

29. Ho S, Woo J, Chan S, Yuen Y, Sham A (1996) Risk factors for falls in the Chinese elderly population. J Gerontol Ser A 51(5):M195-M198

30. Holzer L, Skrbensky G, Holzer G (2009) Mechanical testing of different hip protectors according to a European standard. Int J Care Injured 40:1172-1175

31. Honeycutt P, Ramsey P (2002) Factors contributing to falls in elderly men living in the community. Geriatr Nurs 23(5):250-255

32. Jung D (2008) Fear of falling in older adults: comprehensive review. Asian Nurs Res 2(4):214-222

33. Kane RL, Ouslander JG, Abrass IB, Resnick B (2009) Essentials of clinical geriatrics, 6th edn. McGraw-Hill, New York, pp 265-295, Chapter 9

34. Kanis J, Johnell O, Oden A, Jonsson B, De Laet C, Dawson A (2000) Risk of hip fracture according to the World Health Organization criteria for osteopenia and osteoporosis. Bone 27(5):585-590

35. Kannus P, Sievanen H, Palvanen M, Jarvinen T, Parkkari J (2005) Prevention of falls and consequent injuries in elderly people. Lancet 366(9500):1885-1893

36. Kaptoge S, Jakes R, Dalzell N, Wareham N, Khaw K, Loveridge N, Beck T, Reeve J (2007) Effects of physical activity on evolution of proximal femur structure in a younger elderly population. Bone 40 : 506-515

37. Keskin D, Borman P, Ersoz M, Kurtaran A, Bodur H, Akyuz M (2008) The risk factors related to falling in elderly females. Geriatr Nurs 29(1):58-63

38. Kinirons M, Hopper A, Barber M (2006) Falls in older people. Women Health Med 3:173-174

39. Larson L, Bergmann T (2008) Taking on the fall: the etiology and prevention of falls in the elderly. Clin Chiropr 11(3):148-154

40. Lauritzen J (1996) Hip fractures: incidence, risk factors, energy absorption, and prevention. Bone 18(1):65S-75S

41. Laybourne A, Biggs S, Martin F (2008) Falls exercise interventions and reduced falls rate: always in the patient's interest? Age Ageing $37: 10-13$
42. Ledsham R, Boote J, Kirkland A, Davies S (2006) What is it like to use hip protectors? A qualitative study of the views and nurses and patients. Clin Eff Nurs 951:97-105

43. Lehtola S, Koistinen P, Luukinen H (2006) Falls and injurious falls late in home-dwelling life. Arch Gerontol Geriatr 42:217-224

44. Lin CS, Hsu H, Lay YL, Chiu CC, Chao CS (2007) Wearable device for real-time monitoring of human falls. Measurement 40:831-840

45. Lockhart T, Kim S, Kapur R, Jarrott S (2009) Evaluation of gait characteristics and ground reaction forces in cognitively declined older adults with an emphasis on slip-induced falls. Assist Technol 21:188-195

46. Lockhart T, Woldstad J, Smith J (2003) Effects of age-related gait changes on the biomechanics of slips and falls. Ergonomics 46(12): $1136-1160$

47. Lord SR, Sherrington C, Menz HB (2007) Falls in older people: risk factors and strategies for prevention, 2nd edn. Cambridge University Press, Cambridge

48. Mcclure R, Hughes K, Mckenzie K, Dietrich U, Vardon P, Davis E, Newman B (2010) The population approach to falls injury prevention in older people: findings of two community trial. BMC Public Health. http://www.biomedcentral.com/1471-2458/10/79. Accessed Jan 2011

49. Melton L (1996) Epidemiology of hip fractures: implications of the exponential increase with age. Bone 18(3):121-125

50. Menz H, Morris M, Lord S (1995) Foot and ankle risk factors for falls in older people: a prospective study. J Gerontol Ser A 61(8):866-870

51. Michael Y, Lin J, Whitlock E, Gold R, Fu R, O'Connor E, Zuber S, Beil T, Lutz K (2010) Interventions to prevent falls in older adults. Evidence Syntheses, no. 80

52. Miller W, Speechley M, Deathe B (2001) The prevalence and risk factors of falling and fear of falling among lower extremity amputees. Arch Phys Med Rehabil 82:1031-1037

53. Moyland K, Binder E (2007) Falls in older adults: risk assessment, management and prevention. Am J Med 120:493-497

54. Muir S, Berg K, Chesworth B, Klar N, Speechley M (2010) Quantifying the magnitude of risk for balance impairment on falls in community-dwelling older adults: a systematic review and metaanalysis. J Clin Epidemiol 63:389-406

55. Myers A, Young Y, Langlois (1996) Prevention of falls in the elderly. Bone 18(1):87S-101S

56. Nieuwenhuizen R, Dijk N, Breda F, Scheffer A, Korevaar J, Cammen T, Lips P, Goslings J, Rooij S (2010) Assessing the prevalence of modifiable risk factors in older patients visiting an ED due to a fall using the CAREFALL triage instrument. Am J Emerg Med 28(9): 994-1001

57. Nyan M, Tay F, Mah M (2008) Application of motion analysis system in pre-impact fall detection. J Biomech 41:2297-2304

58. Nyan M, Tay F, Murugasu E (2008) A wearable system for preimpact fall detection. J Biomech 41:3475-3481

59. O'halloran P, Cran G, Beringer T, Kernohan G, Orr J, Dunlop L, Murray L (2007) Factors affecting adherence to use of hip protectors amongst residents of nursing homes - a correlation study. Int J Nurs Stud 44(5):672-686

60. Odasso M, Levinson P, Gore B, Tremblay L, Bergman H (2007) A flowchart system to improve fall data documentation in a longterm care institution: a pilot study. J Am Med Dir Assoc 8(5):300 306

61. Oliver D, Healey F, Haines T (2010) Preventing falls and fall-related injuries in hospitals. Clin Geriatr Med 26(4):645-692

62. Peterson E, Cho C, Koch L, Finlayson M (2008) Injurious falls among middle aged and older adults with multiple sclerosis. Arch Phys Med Rehab 89:1031-7

63. Pinheiro M, Ciconelli R, Martini L, Ferraz M (2010) Risk factors for recurrent falls among Brazilian women and men: the Brazilian Osteoporosis Study (BRAZOS). Cad Saúde Pública Rio de Janeiro 26(1):89-96 
64. Prince F, Corriveau H, Hébert R, Winter D (1997) Gait in the elderly. Gait Posture 5:128-135

65. Pynoos J, Steinman B, Nguyen A (2010) Environmental assessment and modification as fall prevention strategies for older adults. Clin Geriatr Med 26(4):633-644

66. Rubenstein L, Josephson K (2005) Intervenciones para reducir los riesgos multifactoriales de caídas. Rev Esp Geriatria y Gerontol Suppl 1(40):45-53

67. Scheffer A, Schuurmans M, Dijk N, Hooft T, Rooij S (2008) Fear of falling: measurement strategy, prevalence, risk factors and consequences among older persons. Age Ageing 37:19-24

68. Southard V, Dave M, Davis M, Blanco J, Hofferber A (2005) The multiple tasks test as a predictor of falls in older adults. Gait Posture 22:351-355

69. Srygley J, Herman T, Giladi N, Hausdorff J (2009) Self-report of missteps in older adults: a valid proxy of fall risk? Arch Phys Med Rehabil 90(5):786-792

70. Stel S, Smit J, Pluijm SM, Lips P (2004) Consequences of falling in older men and women and risk factors for health service use and functional decline. Age Ageing 33:58-65

71. Stevens J, Olson S (2000) Reducing falls and resulting hip fractures among older women. Home Care Provider 5(4):134-141

72. Stevens J, Sogolow E (2008) Preventing falls: what works. National Center for Injury Prevention and Control, Atlanta. http://www.cdc. gov/ncipc/preventingfalls. Accessed Jan 2011

73. Sturnieks D, Tiedemann A (2008) Falls. International Encyclopedia of Public Health, pp 563-569

74. Svanstrom L, Ader M, Schelp L, Lindstrom A (1996) Preventing femoral fractures among elderly: the community safety approach. Saf Sci 21(3):239-246

75. Teasell R, Mcrae M, Foley N, Bhardwaj A (2002) The incidence and consequences of falls in stroke patients during inpatient rehabilitation: factors associated with high risk. Arch Phys Med Rehabil 83:329-333

76. Tirado P (2010) Fear of falling. Rev Esp Geriatria y Gerontol 45(1):38-44
77. Tromp A, Pluijm S, Smit J, Deeg D, Bouter L, Lips P (2001) Fall-risk screening test: a prospective study on predictors for falls in community-dwelling elderly. J Clin Epidemiol 54:837-844

78. Varas-Fabra F, Martin E, Torres L, Fernández M, Moral R, Berge I (2006) Falls in the elderly in the community: prevalence, consequences and associated factors. Aten Primaria 38(8):450-455

79. Vellas B, Wayne S, Romero L, Baumgartner R, Garry P (1997) Fear of falling and restriction of mobility in elderly fallers. Age Ageing 26: 189-192

80. Venegas K, Padial P, Hernández M, Ortega C, Montes J, Molina B, Dader M (2010) Factors of risk in an elderly population: evaluation scales for the prevention of hip fractures. Rev Esp Cir Ortopédica y Traumatologia 54(3):167-173

81. Weerdestyn V, Niet M, Duijnhoven H, Geurts A (2008) Falls in individuals with stroke. J Rehabil Res Dev 45(8):1195-1214

82. Weilemann Y, Thali M, Kneubuehl B, Bollinger S (2008) Correlation between skeletal trauma and energy in falls from great height detected by post-mortem multislice computed tomography (MSCT). Forensic Sci Int 180(2-3):81-85

83. Worfolk J (1997) Keep frail elders warm!: the thermal instabilities of the old have not received sufficient attention in basic educational programs. Geriatr Nurs 18(1):7-11

84. World Health Organization (2007) WHO global report on falls prevention in older age. World Health Organization, Geneva. http:/ www.who.int/entity/ageing/publications/Falls_prevention7March. pdf. Accessed Mar 2011

85. Yelnik A, Bonan I (2008) Clinical tools for assessing balance disorders. Clin Neurophysiol 38:439-445

86. Yu P, Qin Z, Shi J, Zhang J, Xin M, Wu Z, Sun Z (2009) Prevalence and related factors of falls among the elderly in an urban community of Beijing. Biomed Environ Sci 22:179-187

87. Zur O, Berner Y, Carmeli E (2006) Correlation between vestibular function and hip fracture following falls in the elderly: a casecontrolled study. Physiotherapy 92(4):208-213 